Article

\title{
Between Horizontality and Centralisation: Organisational Form and Practice in the Finns Party
}

\author{
Niko Hatakka \\ Department of Political Science and International Studies, University of Birmingham, UK; E-Mail: n.t.hatakka@bham.ac.uk
}

Submitted: 28 May 2021 | Accepted: 31 August 2021 | Published: 24 November 2021

\begin{abstract}
This article provides the first comprehensive analysis of the Finns Party's (Perussuomalaiset [PS]) formal organisation and how it operates in practice. Following the framework of this thematic issue, to what extent does the PS's organisation follow the mass-party model and how centralised is the party in its internal decision-making? Analysis of party documents, association registries, and in-depth interviews with 24 party elite representatives reveal that the PS has developed a complex organisational structure and internal democracy since 2008. However, the power of members in regard to the party's internal decision-making remains limited, despite the party's leadership having facilitated a more horizontal and inclusionary organisational culture after 2017. The study reveals how the party combines radically democratic elements of its leadership selection and programme development with a very high level of centralisation of formal power in the party executive, and how the party organisationally relies on a vast and autonomous but heterogeneous network of municipal associations. The article also discusses how PS elites perceive the advantages of having a wide and active organisation characterised by low entry and participation requirements, and how party-adjacent online activism both complements and complicates the functioning of the formal party organisation.
\end{abstract}

\section{Keywords}

activism; Finns Party; party democracy; party organisation; populist radical right; social media

\section{Issue}

This article is part of the issue "Right-Wing Populist Party Organisation Across Europe: The Survival of the Mass-Party?" edited by Daniele Albertazzi (University of Surrey, UK) and Stijn van Kessel (Queen Mary University of London, UK).

(C) 2021 by the author; licensee Cogitatio (Lisbon, Portugal). This article is licensed under a Creative Commons Attribution 4.0 International License (CC BY).

\section{Introduction}

Various scholars have argued that European mainstream political parties have lost their connection with their grassroots and ceased to engage in actively fostering party activism (Katz \& Mair, 1995; Mair, 2013). As mainstream parties have become less reliant on massmembership organisations as a means to reach out to the public and to foster collective identities (Mair, 1989, pp. 176-179), they are witnessing falling membership numbers (van Biezen et al., 2012). As part of becoming so-called "cartel parties," mainstream parties' internal representative organs and "the party on the ground" have ostensibly diminished in their political relevance (Katz, 2002; Katz \& Mair, 1995). Simultaneously, right-wing populist parties (RWPPs) have actively started to challenge mainstream political parties' claim to power (Albertazzi \& McDonnell, 2015; van Kessel, 2015). In terms of their organisation, RWPPs have often been regarded as relying on centralised and charismatic leadership whilst remaining organisationally underdeveloped (Betz, 1998; Taggart, 2000). However, more recent empirical evidence suggests that several European RWPPs have developed enduring and complex mass-membership organisations through which they aim to foster loyal communities of activists - in other words, they have been argued to have adopted characteristics of the mass-party model (Albertazzi, 2016; Heinisch \& Mazzoleni, 2016). These findings challenge the view that all right-wing populist mobilisations are fickle, highly personalised, and organisationally lean.

The task undertaken by this thematic issue is to analyse to what extent European RWPPs have invested in building organisations that rely heavily on the 
involvement of activists on the ground, and to what extent the parties also grant members the opportunity to exercise meaningful influence over the party's internal decision-making. Utilising the analytical framework proposed by Albertazzi and van Kessel (2021), this article focuses on the Finns Party (Perussuomalaiset [PS]). Whereas the organisation of RWPPs in other Nordic countries has been studied (e.g., Jungar, 2016; Jupskås, 2016), little research has been done on the PS's current organisational structure or the party organisation's relationship with its members. Arter $(2012,2016)$ researched the early years of the PS, focusing especially on partybuilding as a project led by the long-term party leader, Timo Soini. Arter and Kestilä-Kekkonen (2014) described elements of the party's organisation in the early 2010s as part of their evaluation of the degree of the PS's electoral, internal, and legislative institutionalisation. Koiranen et al. (2017) conducted a survey with PS members providing analysis of the members' sociodemographic background and networks. Therefore, no previous study has made the PS's organisation and intra-party power relations the primary target of research.

This article provides the first comprehensive description and analysis of how the PS is formally structured and how informal organisational practices affect the functioning and centralisation of power within the party organisation. Via the analysis of party documents, association registries, and research interviews conducted with 24 members of the party's elite (see appendices 1 and 2 in the Supplementary File), this study addresses two core research questions. First, to what extent, how, and with what kind of success has the PS built a well-rooted party on the ground, sustained a significant base of members and activists, and attempted to preserve and to further ideological coherence within the party via its formal organisation? Second, how do the PS's organisational form and informal organisational practices affect the degree of centralisation in terms of the party's decisionmaking and internal democracy?

Methodologically, the study relies on qualitative analysis of a large number of semi-structured thematic party elite interviews. The interviews were conducted to gain insight into the PS's internal politics and communication structures, party elites' narratives regarding the methods and reasons for investing in and socialising activists on the ground, and informal practices that might advance or hinder the power of ordinary members. The interviews were also used to interrogate to what extent the party's formal structure and power relations institutionalised in the party's rules hold true in practice, requiring separate analysis of party documents (PS, 2009, 2013, 2021). All of the interviewed individuals have or had held one or several leading positions at different levels of the party organisation. The interviewees included two members of the party leadership, three current or former party secretaries, four members of the parliamentary group, a member of the party office staff, a member of the party executive, and seven regional leaders and six local leaders from
Central Finland and Southwest Finland. To complement the analysis of the research interviews and party documents, a quantitative description of the development of the party's member base and its network of associations was produced using data gathered from the archive of the Finnish Patent and Registry Office (Finnish Patent and Registry Office, 2021) and secondary sources (see appendix 4 in the Supplementary File).

\subsection{Short History of the Finns Party}

The PS (commonly known internationally as the True Finns until 2011) was founded in October 1995 by politicians and activists from the Finnish Rural Party (Suomen Maaseudun Puolue [SMP]). The first decade of the PS was ideologically marked by the SMP's centre-leftist anti-establishment populism that targeted the "corrupt old parties" on behalf of the "forgotten people" of the Finnish periphery (Arter, 2012). As party leader, Timo Soini (1997-2017) built on the SMP's heritage to combine centre-leftist economic policies with socialconservative values, and a nostalgic patriotic longing for a Finnish heartland where one prioritises "home, religion, and the fatherland" (Vares, 2011, p. 33). In its first parliamentary elections in 1999, the PS proclaimed to be "the right-wing party of the poor," but ever since, the party leadership has downplayed ideological connections to both the left and right (Arter, 2016). Under the leadership of Jussi Halla-aho, the party has programmatically shifted economically to the right, heavily fortified its nativism and toned down its Christian and centre-left heritage, and can now be classified as a populist radical right party (Hatakka, 2021).

The PS's rise to power was long and arduous, but in the 2011 elections the party won 39 seats in the Finnish parliament. In 2015, the party lost only one seat and joined a coalition government for two years. Despite the party having appeared stable in its internal composition during the first electoral cycle after becoming a major party (Arter \& Kestilä-Kekkonen, 2014), internal factionalism revolved around the personas of Timo Soini and Jussi Halla-aho. This eventually led to the split of the parliamentary group in 2017 after Halla-aho was elected as party leader (e.g., Nurmi, 2017). Despite initially losing half of its polled support after taking part in government, the party matched its representation in the 2019 parliamentary elections as the second-largest party in Finland. After that, the party's support has continued to grow. Thus, in terms of electoral institutionalisation, the PS has not only been able to create a stable position for itself in the Finnish party system (Arter \& Kestilä-Kekkonen, 2014) but has also managed to strengthen its support and consolidate its ideological direction after a severe internal crisis. Following victorious municipal elections in 2021, the party's recently institutionalised populist radical right alignment was continued as the party's members elected Riikka Purra as Jussi Halla-aho's successor at the party's helm. An explanation for the party's quick 
recovery and apparent stability in the face of internal turmoil and leadership change can be found in the party's rootedness on the ground.

\section{The Finns Party on the Ground}

To evaluate the extent to which the PS has adopted the mass-party model, in the next sections I will analyse the party's organisational extensiveness, practices of member recruitment and socialisation, the role of social media for party activism, and perceived advantages and disadvantages of maintaining a mass-membership organisation.

The PS is an officially registered party (Perussuomalaiset $\mathrm{rp}$ ). The official organs of the registered party at the national level are: (1) party congress (puoluekokous), (2) party executive (puoluehallitus), (3) party council (puoluevaltuusto), (4) advisory assembly (puolueneuvosto), and (5) parliamentary group (eduskuntaryhmä). They facilitate intra-party decision-making and create and implement the party's programmes at the national level. However, to describe the party's organisational form, one cannot just focus on the registered party and its organisational bodies; the key role played by numerous party associations also needs to be recognised. The only official member associations of the PS are the 16 regional associations that each hosts between four and 28 municipal associations. In January 2021, the PS's regional associations hosted a total of 242 municipal associations. Additionally, there were 23 special interest associations that (like the municipal associations) are not officially member associations of the party. Lastly, there were two support associations: the Suomen Perusta think tank and the Pekasus centre for intra-party training. Therefore, in early 2021, the PS's organisation consisted of 284 officially recognised associations with their own rules and organisational bodies (Table 1 ).
Table 1. List of organisations recognised as part of the PS (January 2021).

\begin{tabular}{rll}
\hline 1 & Registered party \\
16 & Regional associations \\
242 & Municipal associations \\
20 & Women's associations \\
1 & Youth association \\
1 & Men's association \\
1 & Entrepreneurs' association \\
1 & Think tank \\
1 & Training centre \\
\hline TOTAL: & 284 & organisational entities \\
\hline
\end{tabular}

The PS's organisation has significantly widened since the late 2000s in terms of the numbers of members and party associations and their territorial coverage. This has happened mainly via the founding of new municipal and special interest associations and the reactivation of defunct regional and local SMP associations. Figure 1 presents a timeline of when PS associations were founded and how large a share of associations that at some point have been part of the party still remain party associations in the early 2020s. The timeline reveals three core findings: (1) The core of the PS's network of municipal associations was inherited from the SMP; (2) the current organisational width of the party organisation was established between 2008 and 2013; and (3) even though the party organisation's territorial expansion has nearly ceased during the current leadership, the party's membership numbers remain on the rise.

During 1995-2007, the PS relied organisationally mostly on the extant network of the SMP's local associations. After the SMP's demise, 117 SMP associations were appropriated as PS associations, at least

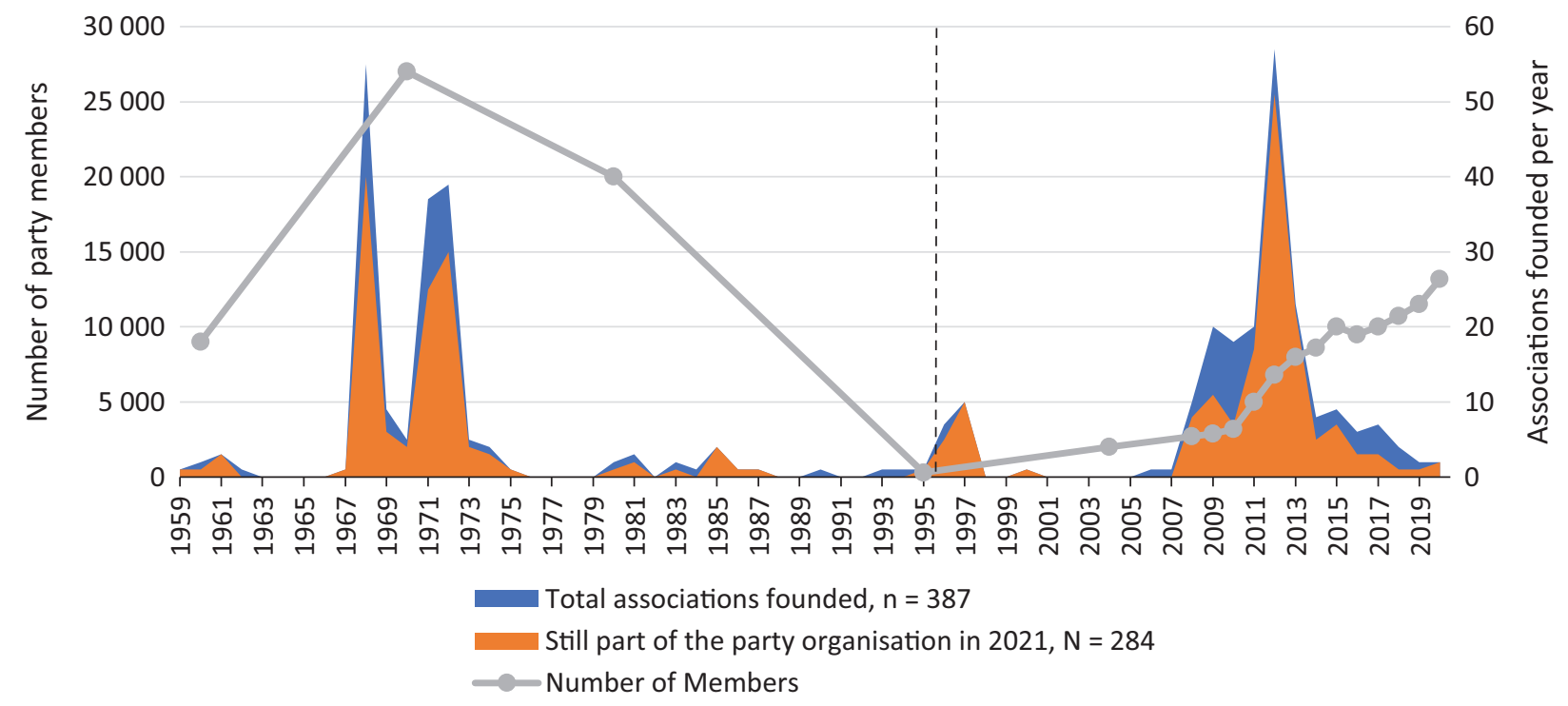

Figure 1. Number of SMP and PS associations founded annually and number of party members 1959-2020 (regarding the sources and method of data collection, see appendices 3 and 4 in the Supplementary File). 
temporarily, and nearly half of the current PS associations date back to the SMP era. In 2008, the PS started a coordinated horizontal expansion (Representative 5) that peaked in 2012, supported by the party securing approximately $€ 6 \mathrm{M}$ of annual state funding by obtaining 39 seats in parliament in 2011. In the years 2008-2013 the PS expanded more than the SMP had ever done, founding 148 new associations. This expansion increased the PS's organisational presence to a respectable $82 \%$ of Finnish municipalities by the elections of 2017. In the 2021 municipal elections, the party had candidates in $98 \%$ of the municipalities and got representation on 284 municipal councils, thus lacking a council seat in only nine municipalities.

The number of PS members remained very low until the beginning of the party's expansion in 2008. Whereas the SMP had a membership of 20,000-27,000 in the 1970s and 1980s, the PS had only a couple of thousand members in 2004, nine years after the party was founded. Overall, it took 13 years for the party's membership numbers to start to increase, but there has been an upward trend ever since. Despite the number of PS members having almost tripled in a decade since early 2011, the number of members remains relatively low when compared to the three other large parties in Finland. However, when evaluating the scale of membership, one must take into account that political party membership is relative rare and has been in decline in Finland since 1980 (Borg et al., 2013, p. 28; Mickelsson, 2021). Thus, the PS-together with the Green League and the Left Alliance-remains an exception as its membership numbers have almost consistently risen throughout the 2010s, whereas the traditional parties' membership numbers have decreased (Borg et al., 2016; Mickelsson, 2021). After the splitting of the parliamentary group in 2017, the party initially lost approximately 400 members, but due to renewed interest in party membership, the party soon recovered and exceeded its previous membership numbers. According to current party elites, the split of the parliamentary group did not affect the functioning of the party organisation detrimentally, except for individual associations that suffered from defections by prominent local leaders (Representatives 4, 8, 12, and 16). Therefore, the party has built an extensive and territorially comprehensive network of local associations with growing membership, and the party's degree of organisation is high.

\subsection{Member Recruitment, Mobilisation, and Socialisation}

Despite membership in the PS having risen since the late 2000s and party elites increasingly viewing members as vital assets for the party, there has been no clear centralised strategic investment in member recruitment from the party's national level (Representatives 3 and 4). The obtaining of new members and the activation of the member base takes place in the municipal associations that are the party's primary organisational presence on the ground. Recruitment activity between associations ranges from passive to very active. All local associations organise so-called "tent events," where local activists set up a stand usually at a marketplace to offer passersby coffee and a chance to chat with local and touring national party representatives. According to all interviewed party elites, such events are the most important source for new members in addition to recruitment via personal contacts. Another universally common route for entry into the party barely involves the formal party organisation, as nearly half of the new members apply for membership on their own initiative, without any prior contact with local party associations or party members (Representatives 1 and 2). Therefore, the motivation for joining the party can arise irrespective of the mobilisation efforts by the formal party organisation.

The national level of the party communicates directly with the party members via the party's paper, online news website, YouTube channel, Facebook page, and regular e-letters from the party office and the parliamentary group. Direct instructions, strategic considerations, and educational materials are disseminated to members mostly via the regional and local associations by using the local leadership as messengers. The municipal associations keep in touch with local members via massemails, phone calls, WhatsApp groups, Facebook pages, and varyingly frequent face-to-face meetings. However, the municipal associations' communication practices are heterogeneous. While in the most active associations the leadership and core activists try to establish a constant connection even with passive party members, in some associations local members barely keep in touch with each other beyond formal routine meetings. According to the interviews, the level of commitment and sense of community among members vary according to the local organisational cultures and styles of leadership. The most active associations organise social events, such as Christmas parties, bowling, and sauna nights, which are described as serving the organisational goal of social bonding between activists. Active municipal and regional associations also organise lectures, seminars, and city hall meetings, most of which are also open to non-members (e.g., Representatives 17 and 20).

The only official requirements for membership in the PS are that members must be 18 years of age and "of good reputation," and they cannot be a member in any other political party (PS, 2009, 2021). Party membership is granted by the party executive, not by local chapters like in most other Finnish parties. Therefore, PS members must separately apply for membership in a local association, but it is not mandatory. According to party elites, an adequate quality of members is ensured via requiring applicants to have local recommenders, or if they have none, the applicant's closest local association is contacted via email to query whether the local leadership has anything against an applicant's membership (Representative 24). Before the meeting of the party 
executive, unknown applicants may also be googled to screen for activities that could prove harmful for the party. In this context, the interviewees specifically mention the monitoring of overt links to the extreme right. But as the party executive may have to process dozens, sometimes even hundreds, of applications during one meeting, "unwanted people" are unavoidably granted memberships (Representatives 4 and 24). The procedures for ensuring quality of members at the local level vary from non-existent to structured interviewing, but in all cases, membership in a municipal association is granted by the municipal board (Representative 22; PS, 2013).

There are few material benefits provided by membership in the PS. Members get a subscription to the party's magazine, Perussuomalainen, and access to the party's online portal, Suomen Uutiset. The only other tangible benefits are the food and refreshments served at events and meetings. The advantage of getting employment is not an important reason for activism at the local and regional levels, as the relatively few jobs within the party organisation are fully centralised in the party office or in the parliamentary office. However, especially for young people, the prospect of advancing in the party's ranks to become, for example, a municipal councillor or an aide to a Member of Parliament can incentivise activism (e.g., Representative 1). The party also provides its activists with training on, for example, municipal administration, association procedures, and social media communications. Intra-party training is organised either directly by local and regional associations, often carried out by the most experienced local party activists and politicians, or it may be provided by the party's national Pekasus training centre (Representatives 1 and 3 ). There are also financial and social reasons for individuals to not join the party, as according to most of the interviewed party elites, potential members may be discouraged by the prospect of harming their career or business or becoming socially stigmatised. The insignificant material advantages of PS membership are confirmed by a survey study, according to which, of all party members in Finland, PS members were least likely to answer that they benefited financially or professionally from their party membership (Koiranen et al., 2017, p. 75).

According to party elites, activism in the PS is motivated especially by the prospect of making a difference and the personal and social gratification provided by being part of a movement. The most prominent narrative is that the key reason for joining and staying in the party is to have a platform to advance the issues on and beyond the party's political agenda both locally and nationally. Activists are also said to be significantly motivated by social interaction, a sense of group membership, and a sense of worth and recognition. According to the interviews, for many activists the social circles found in local party branches and at party congresses are important for acquiring like-minded close friends and acquaintances, which intensifies the activists' commitment. The most committed activists for whom "the party is everything" (Representative 18) voluntarily spend several hours per day on party business. According to party elite narratives, the high level of motivation among activists is the result of the party's attempts to foster a sense of community among its members. However, as the local associations are heterogeneous in their levels of activity, so too do the commitment, motivation, and sense of belonging among activists vary significantly between associations.

According to the party elites, there is a clear organised attempt from the party to ideologically inform and to educate the members participating in the municipal associations. But many of the party's members, let alone supporters, have a very thin or non-existent connection to the party organisation itself. According to the interviews, furthermore, there is often little interest towards the party's communications, even among members. Even though most of the party's formal activism takes place in local associations, almost half of the party members are not members of a municipal association (Representatives 4 and 24). This means that a large share of the party's official members are out of the loop of most of the party's communications to members, faceto-face socialisation, and the formal practices that facilitate the party's internal democracy between party congresses. Additionally, according to party elites' estimates, only a third of the members with membership of a local party association regularly participate in any formal party activities (Representative 8 ). However, activists who physically volunteer in the party's events and associations predominantly have membership both of the party and a municipal association.

\subsection{Internet and Social Media in Party Organisation and Activism}

As many PS members and sympathisers identify with the party via mainstream or online media, the political activism relevant for the party's performance partly takes place outside of the participatory framework provided by the party's formal organisation. Social media especially provide alternative platforms for partyadjacent networking and advocacy, particularly for party members and supporters who are not involved in any of the party associations and for members of inactive, poorly organised, or infighting local associations (Representatives 1 and 3). According to interviewed party elites, members are especially active on Facebook, discussion forums, news platforms' comment sections, and blog platforms. However, more recently YouTube and Twitter, in particular, have become key platforms for both national and local party politicians and activists to voice their opinions. In addition to being viewed as organisational tools that aid activists in their work in party associations, party elites stress the importance of social media as means for activists to promote and to inform the party about political topics they are personally passionate about (Representatives 8, 10, 16, and 19). 
Thus, in addition to its formal network of associations, the party benefits from an online grassroots base comprising networks of members and sympathisers who participate on social media to advance what they perceive as the party's cause. Based on the conducted interviews, however, the formal party organisation has little control, institutionalised strategy, or even understanding of what its online grassroots and local politicians are doing on the internet, as party elites do not view online communications as "official" party communications (e.g., Representatives 3 and 8). Still, most party elites view social media and party supporters' online actions as essential for the dissemination and sharpening of the party's message. Whilst, in general, party elites do not regard the organisation's general online strategy particularly developed when compared to other parliamentary parties (Representatives 6 and 8), the party has repeatedly ranked high in metrics that measure online engagement and following (e.g., Tervo, 2021). Previous research has shown that the party's ability to tap into controversial ideational and stylistic resources, while retaining an appearance of normalcy, has been facilitated by the overlapping of two spheres of activism: one of institutionalised party activism carried out within the formal party organisation and one of party-adjacent online activism (see Hatakka, 2019; Ylä-Anttila, 2020). This is likely to have fed into the prevailing organisational practice according to which the PS tries to avoid publicly intervening in members' online conduct and mostly leaves the style and contents of online communications to the members' own discretion. However, in cases where party secrets have been disclosed or the party's public image has been blatantly or intentionally jeopardised online, both informal and formal disciplinary measures have been conducted at the local and national levels (Representatives 3, 12, 16, and 23).

\subsection{Perceived Advantages and Disadvantages of Fostering an Active Base of Finns Party Activists}

According to party elites, the municipal associations are essential to the PS for conducting on-the-ground campaigning, for establishing and maintaining a presence in local governance, for increasing the party's legitimacy locally and regionally, and for recruiting candidates and party officials. Party members are insignificant for the party as a source of income both nationally and locally (National Audit Office, 2020), and due to the generosity of state funding, the party would be financially viable even with free membership. Taking into consideration that the party organisation consists of 284 officially recognised organisational entities but has only 23 members of staff, the party organisation relies almost entirely on volunteering. Thus, the party organisation's level of professionalisation is very low. Not surprisingly, according to the party elites, the party would not be able to function without activists, especially in municipal elections.
Due to its reliance on volunteers, the PS intentionally keeps the threshold for participating as low as possible. The party does not require long-term membership or prior participation in the party organisation before members can run as candidates or serve in a position of responsibility within the organisation. As individuals can advance very quickly in the party's ranks, this can also cause problems for the party's cohesion and functioning. According to several interviewees, municipal associations are often plagued with conflicts that can arise especially due to the inexperience, incompetence, and mismatched chemistries of local activists. According to local leaders, a single individual may be enough to create a toxic environment in an association, which has led not only to infighting but also to the expelling of members and entire local and regional associations (Representatives 4, 20, and 22). Many interviewed party elites consider the increasing lack of communication control as detrimental to the party's functioning. The problem was especially prominent during the party's organisational expansion in the years 2008-2013, when thousands of people with little knowledge and experience joined in as party activists in newly founded associations. According to a senior Member of Parliament, "during that time anybody could get a position on some executive board" (Representative 1). As after 2017 a good number of the party's most experienced activists have been replaced by newcomers, and the party's membership numbers keep increasing, the party has tried to provide more training and direct guidance to its associations and members (Representative 4).

\section{Centralisation vs. Horizontality in the Finns Party}

The PS having achieved a high degree of organisation and complex procedures for facilitating intra-party democracy does not mean that it empowers its members and party on the ground in terms of internal decisionmaking. The next sections analyse the formal and informal distribution of power within the PS. Figure 2 illustrates the relationships between the PS's institutions: who elects whom and thus to whom the elected bodies are accountable, who grants membership or expels whom, and where each organisational body of the party has representation. There are three levels in the party: the national, the regional, and the municipal level. The national level consists of the different institutional bodies of the registered party: the party congress, party executive board, party council, parliamentary group, and advisory assembly. The national level is linked to the regional levels via institutionalised representation of regional executives on the party council. In turn, the regional level is attached to the municipal level either via municipal executives or assemblies. All other party organs, including municipal council groups, special interest associations, the group of Members of the European Parliament, and the additional support organisations, have little or no institutionalised power in the party. 


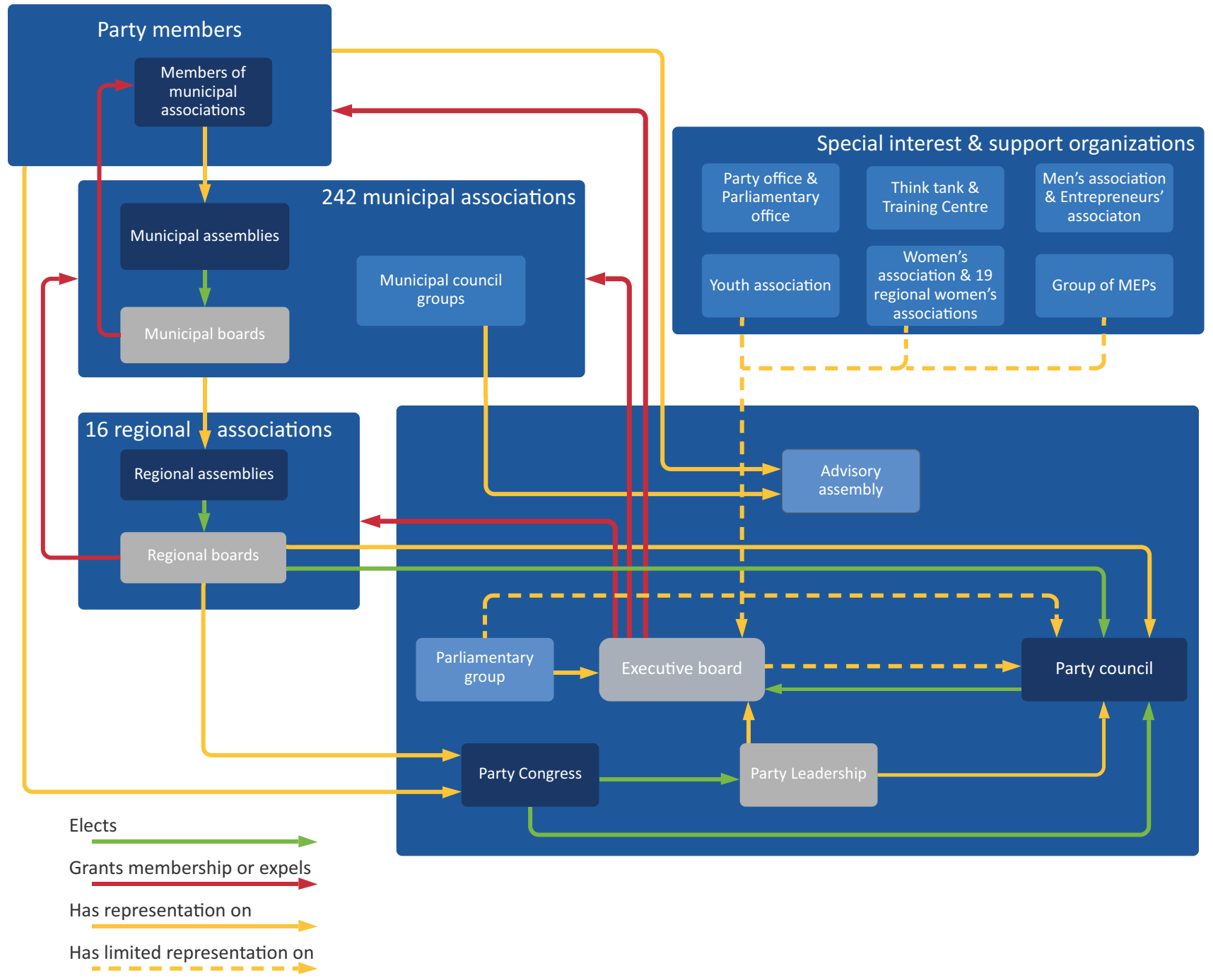

Figure 2. The PS's organisational chart (August 2021).

Unlike most other Finnish parties, in which internal democracy functions via a system of regional delegates, the PS's internal democracy is organised in a dualpronged manner, with two formal routes for party members to influence the national level of the party. The first route goes through party congress, in which party members directly elect the party leadership (in a biennial two-stage direct election) and accept changes to the party's rules (PS, 2009, 2021). The second route for influencing the national level goes via the municipal associations, which elect regional representatives, who then can become members of the regional boards, of the party council, and even of the party executive. So, on the face of it, the PS appears to give a considerable amount of power to its members. However, when analysed closely, both the party's formal structure and several informally institutionalised practices severely curtail the members' influence.

The party executive has the power to affect nearly everything that goes on in the party. It wields power over the party's programmes, approval of national-level election candidates, budget allocation, and hiring of staff.
Most importantly, the party executive controls all individual and institutional party memberships and possesses both formal and informal leverage on the lower party levels. Even though the party executive is accountable to the annual meeting of the party council, this accountability is diminished by two factors. First, the party council has more of a symbolic than an actual role in the party's strategic and programmatic decisions and day-to-day operations. Second, despite the party council being powerful in terms of electing most of the party executive, it has few other significant powers, and its representational legitimacy is limited by how it is elected.

Even though previous statute dictated that the party congress was supposed to elect the non-institutionally assigned seats of the council (PS, 2009), this has not happened in practice due to an originally informal but recently institutionalised organisational norm. In reality, party council seats have been negotiated in advance between regional boards and rubber-stamped by the party congress (Representatives 3 and 4). This longstanding informal practice that was formalised in the party's new rules in 2021 (PS, 2021) makes the party 
executive resilient against takeovers via the party congress. Additionally, as representation on the party council, which elects the majority of the members of the party executive, is ensured via membership at the local level, the fact that relatively few party members have local membership undermines the legitimacy of the oversight of the party's executive organ. Also, despite there being 16 regional associations, there are only seven seats for regional representatives in the party executive, meaning less than half of the regional associations have representation. Even though several of the interviewed party elites were concerned about the overt contention this creates in the regions (e.g., Representatives 4, 5, and 20), the party's rule change of 2021 did not include expansion of the party executive to strengthen regional representation (PS, 2021).

Although the PS's municipal associations operate autonomously in their day-to-day activities, their statutes state specifically that the associations "must follow the party's and the party organs' decisions and instructions" (PS, 2013). The conducted interviews suggest that, in practice, local party officials tend to adhere closely to the decisions and instructions provided by the party office, the party leadership, and the regional boards (e.g., Representatives 4, 22, and 24). Due to the party executive's capacity to exert centralised control over problematic associations, it is theoretically possible for the party board to supress factionalism that might arise locally or regionally. However, party elites describe attempts of controlling the lower levels purely as providing "guidance" and "assistance," and local leaders specifically state that the national level very rarely intervenes in the actions of the local associations. Therefore, as long as the local and regional associations do not cause harm to other party associations or to the party, they are usually able to-and are even expected to-act autonomously. The party executive or the party office intervenes in the local or regional levels only in highly unusual circumstances, as local infighting is handled by prioritising informal means and by following the principle of subsidiarity, meaning local problems should be solved locally. And generally, there is little need for formal interventions, as the party's network of municipal associations is, according to party elites, ideologically rather uniform (Representatives 1, 2, 12, and 16).

\subsection{Formal and Informal Member Power in the Finns Party}

The PS's current organisational form centralises power in the party executive to the extent that most of the key internal decisions can theoretically be made by a small circle of just seven people. However, the interviewed party elites observe that the party's organisational culture has taken a turn towards decentralisation. Even though the party's current formal structure has not significantly changed since 2009, the interviewed party elites stress that, during Jussi Halla-aho's leader- ship, the party developed more of an open and approachable organisational culture, in which activists were welcome to express their concerns and to act on their own ideas regarding the improving of the party's organisation and activities. In addition to the municipal associations having allegedly more room to manoeuvre, members' views regarding the party and its functioning are claimed to be listened to by national leadership and the party office, and the party has also developed institutionalised procedures for consulting its member base in developing the party's programmes and rules (Representatives 6, 12, and 17). However, the extent to which local organisational cultures facilitate horizontal participation depends heavily on the leadership style of local leaders (Representatives 4 and 5). Furthermore, considering that the party executive, after years of intraparty discussion, proposed only minute changes to the party's rules in 2021 (PS, 2021), centralisation of formal power persists in the PS regardless of any increase in informal member power.

In terms of national leadership selection, the PS members have a lot of power. The party leader, the three vice party leaders, and the party secretary are selected in a direct election in party congress where all attending party members have one vote (PS, 2009, 2021). The power of members in candidate selection depends on the type of elections, and there are differences between the regional and municipal associations. In the municipal elections, the local associations draft candidate lists autonomously, but different associations use different means of drafting and approving the lists. In parliamentary elections, where candidacies are in shorter supply, the candidate selection processes tend to be more systematic, partially due to Finnish election legislation. But still, there are notable differences in how the lists are drafted between the regional associations. For example, in the Southwest Finland regional association, some of the names on the list are picked by the regional board based purely on electoral-strategic considerations, but a share of the candidacies is selected via a member vote organised by the region's municipal associations. However, in the end, the party executive may change one fourth of the names on the lists suggested by the regional associations (PS, 2009, 2021)but this power is used sparingly (Representatives 12, 13, and 16). In European Parliament elections, according to the party's 2009 rules, the candidates were supposed to be selected via a member vote, but in practice, the candidates have been directly selected by the party executive. This informal practice was institutionalised into the party's official rules in 2021 (PS, 2021).

For most Finnish parties, the party congress is the institution in which programmatic policy positions are drafted, revised, and ratified. In the PS, it is up to working groups led formally by the party executive to devise programmatic drafts, which are then discussed by the advisory assembly, who make suggestions for revisions. Besides revising and (originally) formally ratifying the 
party's programmatic outputs (PS, 2009), the advisory assembly also serves as an intra-party socialising and networking event (Representatives 3 and 22). Some of the interviewed party elites consider the advisory assembly essential to getting suggestions for revising the party programmes (Representatives 2, 9 and 22), but several interviewees were also sceptical of whether the suggested revisions end up in the final programmes. The sheer logistics of getting feedback and suggestions for revisions from a crowd of hundreds of people during a one-day event reduces the advisory assembly's role as a functional means to ensure horizontal and inclusive formulation of party programmes (Representatives 4 and 8).

Overall, the drafting of the party's national programmes is not transparent, as the working groups operate behind closed doors and include only one or a few high-ranking party politicians, aides, or party office staff (Representatives 2 and 9). However, the process is not entirely centralised, as the working groups use crowdsourcing as a means of accumulating contents for the programme drafts via the local associations (Representatives 17 and 20). In addition to gathering programmatic feedback from the members, proactive expert activists, in particular, are sometimes able to influence the drafting of the programmes. This occurs when they take the initiative to gain access to the working groups or when they are asked directly to contribute (Representatives 9 and 12). After the meeting of the advisory assembly, the working group or the head writer produces the revised final programme, which has thus far invariably been accepted by the party executive. Thus, despite the party going to lengths to facilitate the hearing of its members in the formulation of party policies, the final form of the programmes is ultimately determined by the party's top elite. As party elites view this kind of centralisation as a direct safeguard against the potential radicalisation of party platforms (e.g., Representative 4), it was not surprising that in the party's new rules the power to make programmatic decisions was reserved ultimately for the party executive (PS, 2021). Though the rule change further diminishes formal member power in the PS, it has to be noted that the powers of the advisory assembly were already restricted by several informal practices and the general format of the assembly.

\section{Conclusions: The Finns Party as an Unknowingly Modern Mass-Party}

The PS has a complex and extensive organisational structure and procedures facilitating internal democracy. However, the extent to which it allows its activists to affect the party's internal decision-making in practice remains formally limited. The party developed a comprehensive network of (mostly) autonomous municipal associations during the late 2000s and early 2010s, but in some regions, and especially smaller rural towns, the levels of activity and experience characterising local associ- ations and core activists remain low. Even though the PS provides no material benefits and few exclusive events to its members, the party's communities of activists are characterised by strong collective identities and a high level of ideological coherence that, according to party elites, are fuelled mainly by a sense of purpose and community. However, there are noticeable differences between the cultures, communities, and organisational practices of local associations. In terms of power distribution, the PS is organisationally a Frankenstein's monster combining radically democratic elements of the party congress and the advisory assembly with a weak and incoherently elected party council and an extreme level of centralisation of power in the party executive, whose representativeness and oversight remains limited.

The PS has many formal characteristics of a massparty, as understood by Albertazzi and van Kessel (2021). The party should be regarded as one of the European populist radical right parties that have constructed and maintained a locally rooted, highly articulated, and extensive organisation that aims to foster party activists' commitment and mobilisation (Heinisch \& Mazzoleni, 2016). Even though the party arguably values and needs its activists, both the party's rules and its informal practices severely limit the power of members in the PSa characteristic not atypical of mass-parties, including other populist radical right parties that adopt this organisational model (e.g., Jungar, 2016). However, the current party leadership has avoided using their powers to intervene in the actions of the sub-national levels. This suggests that even a formally centralised party can allow relative autonomy and agency for its associations and individual members. If given a generous reading, centralisation of power in the current PS could be interpreted more as a safeguard against radicalisation than actual lived organisational reality. The PS's post-Soini organisation is showing clear signs of the shedding of its leadercentric legacy (see Arter, 2016) and the development of a more participatory and inclusive organisational culture. Yet the party still clings on to the elite-driven party form of his era. This exemplifies how decentralisation can take place informally within a mass-party-type party organisation even if the top elite is reluctant to share formal power.

The empirical findings presented in this article suggest that the PS can be viewed as an (unknowingly) modern mass-party that utilises not only one but several complementary modes of organisation. Despite activists playing a key role in the party's functioning, the party can be argued to be (nearly) as reliant on state funding and the mediatised leadership of its upper party echelons as are the parties that Katz and Mair (1995) would describe as cartel parties. In addition to benefiting from financial state support, the PS has also found synergies between its mass-membership organisation and less organised online movements. It has been able to enjoy the benefits of the stability of having a formal party organisation, while being boosted by the agility of online activists 
and sympathisers. This has aided the party, for example, in fostering a sense of community and purpose among activists in regions where formal organisational cultures remain underdeveloped. However, cooperation with online movements can also pose challenges for a party's legitimacy, image, and future direction (Hatakka, 2019). For example, while the PS's formal organisational structure was being extended to its current width between 2008 and 2013, the party became an organisational vehicle for overtly radical right demands articulated in movements that were originally parallel to the formal party organisation (Pyrhönen, 2015; Ylä-Anttila, 2020). When combined with the truly decentralised nature of the party's national leadership selection and the low threshold for activists to advance in the party's ranks, this arguably hastened the widespread organisational entrenchment and mainstreaming of the current radical right party regime. At present, the party's official line pertaining to the Covid-19 pandemic and vaccinations is being actively undermined online not only by party sympathisers but also by party activists. Considering that social media are rapidly changing the environment in which party organisations operate, retaining some organisational safeguards can be necessary for sustaining electoral and governmental viability.

Therefore, in the current media environment, even centralised and ideologically coherent mass-parties such as the PS might not be entirely successful in socialising especially locally disengaged or party-adjacent activists into sharing a uniform ideology and disseminating it fully in accordance with the party elites' and the organisation's interest. If a party's activist core drifts too far from the formal organisation and its centralised powers that allow structured policing and fostering of internal ideological cohesion (Albertazzi, 2016; Panebianco, 1988), the party's legitimacy could be jeopardised by radicalisation and marginalisation. This highlights that parties similar to the PS must find a balance between reaping the rewards of providing autonomy for their formal and informal activists and the challenge of knowing when, where, and how to rein them in. The case of the PS reveals that despite online activism manifesting itself seemingly parallel to political parties' membership, institutions, events, and campaigns, it remains noticeably and needlessly overlooked in the party organisation literature-perhaps due to being viewed as external to the functioning of parties.

\section{Acknowledgments}

The support of the Economic and Social Research Council (UK) is gratefully acknowledged (Grant Ref: ES/R011540/1).

\section{Conflict of Interests}

The author declares no conflict of interests.

\section{Supplementary Material}

Supplementary material for this article is available online in the format provided by the author (unedited).

\section{References}

Albertazzi, D. (2016). Going, going,...not quite gone yet? "Bossi's Lega" and the survival of the mass party. Contemporary Italian Politics, 8(2), 115-130.

Albertazzi, D., \& McDonnell, D. (2015). Populists in power. Routledge.

Albertazzi, D., \& van Kessel, S. (2021). Right-wing populist party organisation across Europe: The survival of the mass party? Introduction to the thematic issue. Politics and Governance, 9(4), 224-227.

Arter, D. (2012). Analysing successor parties: The case of the True Finns. West European Politics, 35(4), 803-825.

Arter, D. (2016). When new party X has the "X factor": On resilient entrepreneurial parties. Party Politics, 22(1), 15-26.

Arter, D., \& Kestilä-Kekkonen, E. (2014). Measuring the extent of party institutionalisation: The case of a populist entrepreneur party. West European Politics, 37(5), 932-956.

Betz, H.-G. (1998). Introduction. In H. G. Betz \& S. Immerfall (Eds.), The new politics of the right: Neo populist parties and movements in established democracies. St. Martin's Press.

Borg, S., Kiilakoski, T., Mykkänen, J., Myllyniemi, S., Pekola-Sjöblom, M., Piipponen, S.-L., \& Pikkala, S. (2013). Demokratiaindikaattorit 2013 [Democracy indicators 2013]. Finnish Ministry of Justice.

Borg, S., Kestilä-Kekkonen, E., \& Westinen, J. (2015). Demokratiaindikaattorit 2015 [Democracy indicators 2015]. Finnish Ministry of Justice. https:// www.vaalitutkimus.fi/fi/kiinnittyminen/puolueiden_ jasenmaarien_kehitys.html

Finnish Patent and Registry Office. (2021). Registry of associations. https://yhdistysrekisteri.prh.fi

Hatakka, N. (2019). Populism in the hybrid media system: Populist radical right online counterpublics interacting with journalism, party politics, and citizen activism. University of Turku Press.

Hatakka, N. (2021). Officially populist radical right: The Finns Party's ideological positions and key policies since 2017. Unpublished manuscript.

Heinisch, R., \& Mazzoleni, O. (2016). Comparing populist organizations. In R. Heinisch \& O. Mazzoleni (Eds.), Understanding populist party organisation: The radical right in Western Europe (pp. 221-246). Palgrave Macmillan.

Jungar, A.-C. (2016). The Sweden Democrats. In R. Heinisch \& O. Mazzoleni (Eds.), Understanding populist party organisation: The radical right in Western Europe (pp. 189-219). Palgrave Macmillan.

Jupskås, A. (2016). The Norwegian Progress Party: 
Between a business firm and a mass party. In R. Heinisch \& O. Mazzoleni (Eds.), Understanding populist party organisation: The radical right in Western Europe (pp. 159-187). Palgrave Macmillan.

Katz, R. (2002). The internal life of parties. In K. R. Luther \& F. Müller-Rommel (Eds.), Political parties in the new Europe (pp. 87-118). Oxford University Press.

Katz, R., \& Mair, P. (1995). Changing models of party organization and party democracy: The emergence of the cartel party. Party Politics, 1(5), 5-28.

Koiranen, I., Koivula, A., Saarinen, A., \& Räsänen, P. (2017). Puolueiden rakenteet ja verkostot [Party structures and networks]. Kaks.

Mair, P. (1989). Continuity, change and the vulnerability of the party. West European Politics, 12(4), 169-188.

Mair, P. (2013). Ruling the void: The hollowing of Western democracy. Verso.

Mickelsson, R. (2021). Suomen puolueet-Vapauden ajasta maailmantuskaan [Parties of Finland-From the age of freedom to Weltschmerz]. Vastapaino.

National Audit Office. (2020). Finns Party's financial statements 2009-2018. https://www.vaalirahoitus valvonta.fi/fi/index/puoluetukiilmoituksia/ ilmoituslistaus/tilinpaatostiedot

Nurmi, L. (2017). Perussuomalaisten hajoamisen historia [The history of the breaking up of the Finns Party]. Into.

Panebianco, A. (1988). Political parties: Organisation and power. Cambridge University Press.

PS. (2009). Perussuomalaiset rp:n säännöt [Rules of the PS]. https://www.perussuomalaiset.fi/tietoa- meista/perussuomalaiset-rpn-saannot/?doing_wp_ cron $=1587637569.2313420772552490234375$

PS. (2013). Perussuomalaiset rp:n paikallisyhdistyksen säännöt [Rules of the PS's municipal associations]. https://www.perussuomalaiset.fi/wp-content/ uploads/2013/08/ps_paikallisyhdistyksen_saannot. pdf

PS. (2021). Sääntömuutosesitys [Proposition for revising the PS's rules]. https://www.perussuomalaiset.fi/ tutustu-saantomuutosesitykseen

Pyrhönen, N. (2015). The true colors of welfare nationalism: Consolidation of neo-populist advocacy as a resonant collective identity through mobilization of exclusionary narratives of blue-and-white solidarity. University of Helsinki.

Taggart, P. (2000). Populism. Open University Press.

Tervo, E. (2021, May 13). Sanna Marinin somevalta on niin suuri, että hän lyö yksin muut puolueet [Sanna Marin's social media power alone beats other parties]. Yle. https://yle.fi/uutiset/3-11909662

van Biezen, I., Mair, P., \& Poguntke, T. (2012). Going, going,...gone? The decline of party membership in contemporary Europe. European Journal of Political Research, 51(1), 24-56.

van Kessel, S. (2015). Populist parties in Europe: Agents of discontent? Palgrave Macmillan.

Vares, V. (2011). Oikeistopopulismin monet kasvot [Many faces of right-wing populism]. Toivo.

Ylä-Anttila, T. (2020). Social media and the emergence, establishment and transformation of the right-wing populist Finns Party. Populism, 3(1), 121-139.

\section{About the Author}

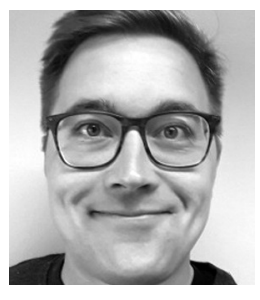

Niko Hatakka (PhD) is a research fellow at the Department of Politics and International Studies (POLSIS) at the University of Birmingham. His research focuses on the populist radical right, party organisation, the relationship of populism and media, online activism, political communication, and media platforms. He is also a visiting fellow at the Centre for Parliamentary Studies at the University of Turku. 